\title{
Tracking and Influencing Learning Motivation
}

\section{Brad Visgatis \\ Osaka International University \\ Masao Tada \\ Osaka International University}

\section{Reference Data:}

Visgatis, B. \& Tada, M. (2020). Tracking and influencing learning motivation. In P. Clements, A. Krause, \& R. Gentry (Eds.), Teacher efficacy, learner agency. Tokyo: JALT.

https://doi.org/10.37546/JALTPCP2019-17

This paper reports on the incorporation of a motivational tracking system and regular interventions designed to address issues in motivation in an intensive English program at a Japanese university. Characteristics of the system are described and data are discussed. Ten intervention sessions focused participants' $(N=40)$ attention on aspects of motivation, including goal-setting, habit formation, and imagery. The results indicate that motivational levels rose steadily during the term and suggest that motivation is not a static trait; rather, it is a state which can be influenced through appropriate interventions. The application of motivational interventions is discussed.

本稿は、日本の男女共学大学の英語インテンシブ・プログラムにおける英語学習動機の追跡システムと定期的計画的な学 習動機を高めることを狙った教育的介入についての報告である。学習動機を高める教育的介入システムの特徴とその結果に ついて、収集したデータに基づいて分析を行つた。その結果、2クラスにおける参加者 $(\mathrm{N}=40)$ の学習動機レベルは当該学期中

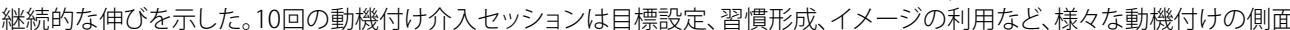
に学習者の注章を集中させる上うに組み立てた。本結果から、学習動機は、固定的な特性ではなく学習期間を通して適切な教 育的介入を行なうことで影響を与えることができる、变化しうる心的状熊であることが示唆された英語学習プログラムを効 果的なものにする為の、学習動機を高める様々な教育的介入についての議論を行つた。 otivation is a critical issue for educators, whether that of a student, a class, or a program. Traditionally, educational motivation was viewed as a trait (see Weiner, 1990, for a history of this research), and researchers used cross-sectional data to investigate motivational concepts or explore connections with performance or other selfreported variables (e.g., Irie, 2003). Kimura, Nakata, and Okumura (2001) administered a 50 -item survey to confirm six motivational factors among 1,027 participants. Yamashiro and McLaughlin (2001) modified and translated Gardner's Attitude/Motivation Test Battery, then administered it to two groups to create a model of English-language learner motivational factors for Japanese university students. Yashima, Zenuk-Nishide, and Shimizu (2004) reported on two studies, each based on a single survey, which correlated learner motivation and willingness to communicate. These, and numerous other studies, considered motivation a trait that could be measured at one point in time.

Language education researchers next began to consider whether motivation was, in fact, a state that could be changed or even generated. Dörnyei (2003), summarizing L2 studies in motivation, argued for a practical framework for helping teachers motivate learners. Gardner, Masgoret, Tennant, and Mihic (2004) suggested it consisted of states "amenable to change" (p. 2). Rost (2006) advocated ways to generate motivation. This led to a view recognizing trait and state aspects and an understanding that motivation levels and types may change over time (Dörnyei, Maclntyre, \& Henry, 2014). As such, monitoring motivation multiple times, rather than conducting an inventory of motivation at one point, might help determine how students are progressing and how well a program meets student needs. Furthermore, researchers began suggesting interventions to modify motivation (e.g., Dörnyei, 1994; Dörnyei, Muir, \& Ibrahim,

2014). In short, these studies indicated that a new approach to motivational research was needed. Therefore, we explored how to generate positive changes in learner motivation and monitored these during a semester. 


\section{The Study}

Setting: Intensive English Program (IEP)

This IEP is a 2-year program that consists of 10 courses and 810 hours of study. Each course meets either 180, 270, or 360 minutes per week. All courses are taught in English by L1-English-speaking teachers and focus on academic English skills. This competitive program accepts a maximum of 40 first-year students annually. However, in many years, only 25 to 30 students meet entry requirements. IEP students have opportunities to study abroad beyond those available to students following the regular curriculum, making it attractive to applicants.

Regardless of the number accepted, students are placed into two sections based upon proficiency (IEP-1 and IEP-2). All must meet strict attendance and performance standards to remain, and the regular evaluations, demanding assignments, and overall rigor mean that a few students must transfer to the less demanding general language curriculum each year.

During the IEP's 18-year history, various procedures, systems, and components have been implemented which foster a unique identity within the university and enable close monitoring of students' progress. Following each academic year, teachers have identified avenues for improvement and implemented these for the next cohort. In previous years, issues in motivation were identified and steps taken to address these. For the 2019 academic year, components to influence and track motivation were added. These included: (a) motivation intervention sessions to familiarize students with and focus on different aspects of motivation; (b) a motivational tracking system to collect information about students' motivation (current level, prior level, attribution for any change, and other relevant data); and (c) an individual advising system in which students maintained a study record and met regularly with IEP advisors (not necessarily one of their teachers). Information gathered through the motivational tracking system was shared with advisors. These components were added to determine how motivation could be maintained through focused awareness on its importance for language learning.

Results from (a) the motivational intervention sessions and (b) the motivational tracking system are discussed in this paper. The main questions are:

1. What individual and group motivational trends can be observed?

2. How can the collected data be used to improve the program?

3. What are the motivating and demotivating factors cited by participants?

4. What are the benefits and limitations to adoption of these systems?

\section{Participants}

Participants consisted of 40 first-year students (female $=24$; male $=16$ ) enrolled in two intact classes of 20 students in the IEP at a mid-sized coeducational university in western Japan. (Two male students dropped out at the end of the first semester.) Participant ages ranged from 18.37 to 20.97 years old $(M=18.92)$. TOEIC tests were administered in both April $(n=38, M=334.87, S D=113.65)$ and August $(n=37, M=398.38, S D=112.87)$. Age, gender, and TOEIC proficiency were not considered in our analyses.

\section{Informed Consent}

The researchers followed institutional protocols for research with intact class groups for data collected as part of normal course work. This includes informing participants of the use of the data for research, maintaining anonymity, and providing opportunities to remove data from presentations outside the institution. As data were a component of the program and used for program improvement and student assistance, students were required to participate in classroom activities. Information about course requirements, including explanations of the motivational data collection, were written in Japanese. Participants were informed that survey feedback was optional and bore no connection to course grades, and that this information would be used to improve the program, assist their advisors, and provide anonymized information for use in research reports. All participants were regularly given the opportunity to remove their data from any presentation of information to those outside the institution. None of the participants opted to withdraw.

\section{Motivation Intervention Sessions}

Two teachers conducted a series of motivational sessions (see Table 1). These explained different aspects of motivation and had participants engage in motivation-related activities. Monday was chosen because it enabled teachers to make announcements, disseminate information, focus student attention on the week ahead, have students reflect on the previous week, and gather feedback. Though planned for every Monday, unexpected personnel changes reduced this to 10 sessions. Each session took 20 to 30 minutes. During the sessions, both IEP classes gathered in one room. Sessions were conducted primarily in Japanese because it is preferable for data collection to use the first language of the participants. This was appropriate given the participants' TOEIC scores $(M=334.87)$. Sessions targeted goals and goal setting, especially setting shortterm and longer-term goals (e.g., Muir \& Dörnyei, 2013); establishing positive learning habits; using imagery to self-motivate (e.g., Dörnyei, Muir \& Ibrahim, 2014); developing 
an image of one's future, ideal self (e.g., Dörnyei, 2009); learning strategies (e.g., Oxford \& Ehrman, 1995); identifying and emulating personal positive language role models (e.g., Morgenroth, Ryan, \& Peters, 2015); and understanding out-of-class English-related time management (Visgatis, 2014). Each of these was considered both salient to participants and amenable to outside influence.

\section{Table 1. Targeted Area of Motivation and Content Details}

Target Content

Goal setting Explained mastery and performance goals; asked students to consider goal time frames (daily, weekly, semesterly); pointed out the necessity of monitoring goal attainment; asked students to set and report weekly and semesterly goals (e.g., Kimura, Nakata, \& Okumura, 2001).

Habit Explained the importance of establishing study and performance formation habits; taught techniques for habit formation; asked students to establish a study schedule and mentally prepare before each class session to use English (e.g., Duhigg, 2012).

Imagery Explained about how imagery could be used to help self-motivate; had students develop useful images (e.g., Dörnyei \& Chan, 2013).

Future self Asked students to construct a 5-year, post-graduation self-image and to list concrete intermediary steps that would lead them to become that person (e.g., Dörnyei \& Chan, 2013).

Strategies Introduced learning strategies; collected information about strategy use; administered the Strategy Inventory for Language Learning (Oxford \& Burry-Stock, 1995); had students discuss strategy use and select previously unused strategies to try; provided feedback (e.g., Oxford \& Ehrman, 1995).

Role Models Explained the usefulness of positive role models; asked students to nominate two role models (an IEP classmate and someone outside); had students discuss their role models' characteristics (e.g., Duff \& Uchida, 1997).

Time Use Shared results from previous IEP students' English-related out-of-class time use; asked students to maintain a one-week time journal (Visgatis, 2014).

\section{Other Impacting Factors}

In addition to the motivational intervention sessions, we anticipated that other elements could influence motivation, including:

- joint events for 1st- and 2nd-year IEP students (e.g., Senior Moment lecture about study abroad from previous IEP students, all IEP Treasure Hunt)

- individual advising sessions conducted two to three times each semester to address student concerns and motivational management

- feedback to students concerning their weeks 5 and 10 progress reports and current grades

- participation in the non-IEP, on-campus English conversation program (English Island).

\section{Motivation Tracking}

Motivation was tracked using a series of surveys, with three to eight items each, in Japanese using the university's learning management system (LMS) (Moodle, 2019). Each survey asked How motivated were you to study English last week? Like the other items in the surveys, participants selected a response on a 5-point Likert scale. Other survey questions assessed specific points addressed during weekly sessions to gather more detailed information concerning changes in motivation from the previous week, attributions for any perceived change, and the impact of the previous session. Table 2 shows the themes for the 10 surveys. This retrospective motivational assessment is an outgrowth from research which examined motivational change over the past several years (e.g., Hayashi, 2005; Sawyer, 2006). In this project, participants reported on the previous week's motivation. (Tracking surveys are available upon request.) 
Visgatis \& Tada: Tracking and Influencing Learning Motivation

Table 2. Survey Content by Date and Session

\begin{tabular}{|c|c|c|c|c|c|c|c|c|c|c|}
\hline & April & & May & & & June & & & July & \\
\hline & 22 & 6 & 20 & 27 & 3 & 10 & 24 & 1 & 8 & 15 \\
\hline & S1 & $\mathrm{S} 2$ & S3 & S4 & S5 & S6 & S7 & S8 & S9 & $\mathrm{S} 10$ \\
\hline Motivational level & O & & 0 & 0 & O & O & 0 & O & 0 & O \\
\hline Motivational change & ○ & & 0 & O & 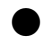 & O & 0 & & O & 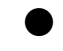 \\
\hline $\begin{array}{l}\text { Motivational change } \\
\text { attribution }\end{array}$ & & & & & & O & 0 & & 0 & \\
\hline Out-of-class English tim & & & & & & & & & & \\
\hline Out-of-class English use & O & & 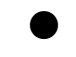 & O & ? & & & & & \\
\hline Goal setting & & & & & & & & & & \\
\hline Goal attainment & & & & & & & & & & \\
\hline Purpose for studying Eng & & & & & & & & & & \\
\hline Future self & & & & & & 0 & & & & \\
\hline Strategies & & & & & & & & & & \\
\hline Role models & & & & & & & & & & \\
\hline English Island & & & 0 & & & & & & & \\
\hline IEP events & & & & & & & & & & \\
\hline General IEP satisfaction & & 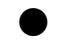 & & $\mathrm{C}$ & & & & & & 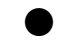 \\
\hline
\end{tabular}

Note. IEP = intensive English program; $\mathrm{S}$ = session.

Each survey also probed areas related to one of the motivational intervention session topics and/or other factors from the previous week. This served to (a) focus participants' attention on aspects of motivation under their control and (b) gather information for individual advising sessions and classroom interventions. Participants used smartphones to complete surveys.

\section{Results}

\section{Individual Motivational Levels}

Weekly motivational levels varied widely (see Table 3). Some weeks, participants rated their motivation as generally high (responses of 4 or 5 on the 5 -point scale). Other weeks, the same participant registered lower levels of motivation (responses of 1 or 2) (shaded areas in Table 3). Overall, the reported motivation levels of most participants increased during the semester. The averages for the first three and last three sessions were used to calculate the change in the participants' overall motivational level during the study period. Thirty-three of the participants showed a positive increase in reported motivational level. Participant 34 showed the greatest increase in average motivation (3.00) and participants $23,29,26$, and 37 had an increase of 2.00. Two participants' (31 and 39) motivational levels were unchanged. Three participants (16,35, and 14) reported decreasing levels (-0.33, -0.51 , and -0.67 respectively). Advisors were informed of low initial motivation for participants 26, 29, and 34 (level 1) and helped these participants resolve their issues. Subsequent reports of motivation were higher. Unfortunately, participants 16 (average change $=-0.33$ ) and 39 (average change $=0.00)$ persistently reported low motivation (levels 2 or 1 ) despite advisor intervention. Both had to leave the program. 
Table 3. Reported Motivational Levels by Student for Each Session

\begin{tabular}{|c|c|c|c|c|c|c|c|c|c|c|c|c|c|c|c|c|c|c|c|c|c|}
\hline \multicolumn{11}{|c|}{ Session } & \multicolumn{11}{|c|}{ Session } \\
\hline$\#$ & 1 & 2 & 3 & 4 & 5 & 6 & 7 & 8 & 9 & 10 & $\#$ & 1 & 2 & 3 & 4 & 5 & 6 & 7 & 8 & 9 & 10 \\
\hline 1 & 2 & 2 & 2 & 2 & 3 & 2 & 3 & 3 & 4 & 4 & 21 & 2 & 2 & 3 & & 3 & 4 & 3 & 3 & 3 & 3 \\
\hline 2 & 3 & 3 & 3 & 3 & 4 & 4 & 4 & 4 & 3 & 3 & 22 & 2 & 3 & & & 4 & 4 & 2 & 4 & 4 & 3 \\
\hline 3 & 3 & 2 & 4 & 4 & 5 & 5 & 4 & 5 & 4 & 5 & 23 & 2 & & 2 & & 4 & 5 & 5 & 4 & 4 & 4 \\
\hline 4 & 2 & 3 & 3 & 3 & 4 & 4 & 4 & 4 & 4 & 4 & 24 & 3 & 2 & & & 5 & 5 & 2 & 2 & 5 & 5 \\
\hline 5 & 2 & 2 & 2 & 3 & 5 & 4 & 2 & 3 & 3 & 2 & 25 & 3 & 3 & 3 & & 4 & 3 & 4 & 4 & & 5 \\
\hline 6 & 2 & 3 & 3 & 3 & 4 & 3 & 4 & 4 & 4 & 4 & 26 & 1 & 3 & & & 4 & 4 & 3 & 3 & 3 & 3 \\
\hline 7 & 3 & 4 & 4 & 4 & 5 & 4 & 5 & 5 & 5 & 5 & 27 & 2 & 3 & 2 & & 2 & 4 & 3 & 3 & 3 & \\
\hline 8 & 2 & 2 & 3 & 3 & 4 & 3 & 4 & 3 & 2 & 4 & 28 & & & & 3 & 4 & 4 & 5 & 4 & 4 & 5 \\
\hline 9 & 3 & 2 & 3 & 3 & 4 & 4 & 4 & 4 & 4 & 4 & 29 & 2 & & & & 2 & 3 & 1 & 3 & 4 & 5 \\
\hline 10 & 3 & 1 & 3 & 2 & 3 & 3 & 3 & 3 & 3 & 3 & 30 & 2 & & & & 3 & 5 & 4 & 2 & 3 & 2 \\
\hline 11 & 3 & & 3 & 3 & 5 & 5 & 4 & 4 & 4 & 5 & 31 & 2 & 2 & & & 2 & 2 & 2 & 1 & 3 & \\
\hline 12 & 3 & & 3 & 3 & 4 & 3 & 4 & 4 & 4 & 3 & 32 & & 3 & & & 3 & 3 & 3 & 4 & 4 & 4 \\
\hline 13 & 3 & & 3 & 2 & 5 & 5 & 3 & 5 & 4 & 3 & 33 & & & 2 & 3 & 3 & 4 & 3 & & 3 & 4 \\
\hline 14 & 2 & 4 & 3 & & 4 & 2 & 4 & 2 & 2 & 3 & 34 & 1 & 1 & & 1 & & 1 & & 4 & 4 & 4 \\
\hline 15 & 2 & 3 & 3 & & 5 & 4 & 3 & 3 & 4 & 3 & 35 & 3 & 3 & 3 & & 3 & 4 & & 3 & & 2 \\
\hline 16 & 2 & 2 & 3 & & 3 & 3 & 2 & 2 & 2 & 2 & 36 & 2 & 2 & & & 3 & 4 & 3 & 4 & & \\
\hline 17 & 2 & 2 & 3 & & 3 & 4 & 3 & 3 & 3 & 3 & 37 & 2 & 2 & & & 4 & 4 & 5 & & 4 & \\
\hline 18 & 2 & 4 & 3 & & 2 & 4 & 5 & 4 & 4 & 4 & 38 & & & & & 4 & 4 & 3 & 3 & & 3 \\
\hline 19 & 3 & 2 & & 3 & 4 & 4 & 3 & 4 & 3 & 4 & 39 & 1 & 1 & & & & & & 1 & 1 & 1 \\
\hline 20 & 2 & 2 & 3 & 3 & 3 & 3 & 3 & 2 & 3 & & 40 & & 3 & & & & 4 & 4 & & 4 & \\
\hline
\end{tabular}

Note. Participants 1 to 20 were in IEP-2, the upper-level group; participants 21 to 40 were in IEP-1. Shading indicates ratings below 3 on a 5-point Likert scale. Blanks indicate absence or data was not collected. The IEP-1 teacher forgot to remind students to complete session 4 surveys, though three submitted it. \# = participants' number.

\section{Group Motivational Patterns}

The researchers calculated average motivation levels and plotted motivational trend lines for the IEP classes after intervention sessions (see Figure 1). The figure includes the session topics and other factors that might have influenced motivation. Although it is tempting to draw conclusions regarding the influence of various factors, caution must be used as data sets were incomplete, sample sizes were small, and the motivational measure consisted of only one item (How motivated were you to study English last week?). These factors preclude use of statistical procedures to determine significance.

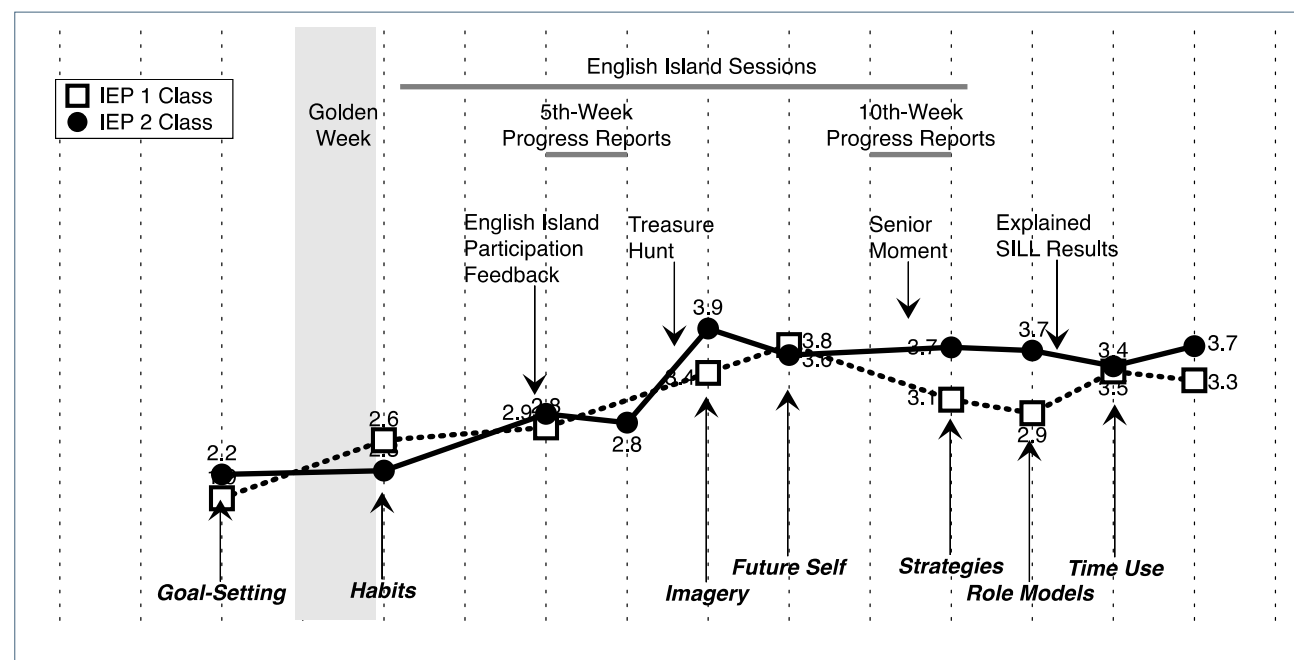

Figure 1. Average reported motivational level for prior week by class, session topics (below trend lines), and other factors (above trend lines). Note. Session 4 data were incomplete for IEP-1 and are excluded. IEP = intensive English program; English Island = on-campus conversation program; Mid-Term Feedback = week-5 and week-10 performance reports; Senior Moment = study-abroad lecture by students from previous IEP cohorts. Treasure Hunt = all IEP competition to familiarize 1st-year students with campus and create links between cohorts.

The participants' motivational levels showed an increasing trend during the term (see Figure 1). Each of the 10 sessions covered different aspects of motivation (see Table 2).

Goal setting and goal attainment were covered in session 1, the third week of the term. 
Two weeks later, following the annual Golden Week holiday, IEP-1 class showed a slight increase in motivation while IEP-2's was unchanged. During session 2, the focus was on habit formation and motivation as a state. Two weeks later (May 20), session 3 covered outof-class English use (Visgatis, 2014). Motivational levels rose for both classes. Introduction of the English Island program could have contributed to this. Week-5 progress reports were distributed between sessions 3 and 4 (May 20 to May 27), which might have depressed motivation at session 4 . However, there was a jump in self-perceived levels of motivation between sessions 4 and 5 (May 27 to June 3) when the treasure hunt event was held. Session 5 focused on imagery (e.g., Dörnyei, Muir, \& Ibrahim, 2014). IEP-1 reached its peak motivational level the following week while IEP-2 continued an upward trend (session 6 : IEP-1 =3.9; IEP-2 = 3.4). Motivation levels rose slightly for IEP-1 and dipped slightly for IEP2 following session 5 (imagery), though both classes showed the same level of motivation at session 6. Session 6 (June 10) focused on a future self (Dörnyei, 2009) and motivational change attribution (e.g., Dörnyei \& Csizár, 1998).

From this point to the end of the term, the motivation levels of IEP-2 were always a little higher than IEP-1's. Motivation session 7 (June 24), followed the Senior Moment activity and distribution of week-10 progress reports. Session 8 covered strategies (e.g., Dörnyei, 1994; Dörnyei \& Csizár, 1998) and the importance of role models (e.g., Dörnyei, Muir, \& Ibrahim, 2014). Following session 9, time use (Visgatis, 2014), motivational levels drew close again. At session 10 (July 22), motivational levels for both classes were below their peak (IEP-1 max. $=3.8$, session $10=3.3 ;$ IEP- 2 max. $=3.9$, session $10=3.7$ ), though above the initial level of motivation for both classes (IEP- $1=2.1$; IEP-2 $=2.2$ ). The data reported from the question How motivated were you to study English last week? offered insights into the program and raised the question such as What caused the IEP-1 class (lower level students) to lose motivation during the $10^{\text {th }}$ and $11^{\text {th }}$ weeks (as reported on the $11^{\text {th }}$ and $12^{\text {th }}$ week surveys)? After consultation with program teachers, the researchers believe the two most likely reasons are either that (a) IEP-1 students realized after the Senior Moment lecture that they might not qualify for study-abroad scholarships or (b) the week-10 progress reports showed lower than expected grades and the need for additional effort on their part.

\section{Individual Motivating Factors}

Asking students to comment on what helped increase or decrease their motivation level provided further insights. The researchers classified comments into broad thematic

categories of either motivators $(n=67)$ (see Table 4$)$ or demotivators $(n=25)$ (see Table 5).

The two most common motivators were assignments $(n=21)$ and personal goals $(n=14)$. It is interesting to note that while personal goals are internally determined, the main driver of motivation seemed to be external: assignments, performance, and teacher interaction.

Table 4. Items Classified as Motivators ( $n=67$ ) in Participants' Comments

\begin{tabular}{lcl}
\hline Item & Count of comments & \multicolumn{1}{c}{ Comment } \\
\hline Assignments & 21 & \\
Confidence & 7 & talked with a foreigner \\
Contact & 1 & watching movies, English Island, Senior Moment \\
Events & 10 & \\
Goals & 14 & bad test results, perception classmates were better \\
Performance & 6 & consultations \\
Teacher & 8 & \\
\hline
\end{tabular}

Table 5. Items Classified as Demotivators $(n=25)$ in Participants' Comments

\begin{tabular}{lcl}
\hline Item & Count of comments & Comment \\
\hline Anxiety & 2 & no test \\
Assignment (-) & 1 & end of English Island \\
Event (-) & 1 & \\
Health & 5 & cannot focus on study \\
Self-control & 3 & \\
Time & 13 & \\
pressure & & \\
\hline
\end{tabular}

Note. $(-)=$ negative motivator.

Far fewer comments were considered demotivators $(n=25)$ (see Table 5). These were categorized as (a) forces beyond participants' perceived areas of control (health, time pressure, lack of self-control) and (b) the elimination of a previous motivator (extension of deadlines, elimination of enjoyable English activities). The most frequent demotivator was time pressure $(n=13)$, suggesting this should be addressed early in motivational interventions. Although most comments were one or two words, they provide insights 
and avenues for future research, including specific interventions that might create positive motivational outcomes.

\section{Discussion}

The data suggest that motivational interventions can have a direct influence on students' motivational levels, confirming the view that motivation is as much a state as a trait (e.g., Dörnyei, 2003; Dörnyei, MacIntyre, \& Henry, 2014). When viewed as a state, the classroom teacher becomes a motivator rather than a monitor. Moreover, it allows educators to consider how to implement interventions, such as those used in this study, that develop awareness among students of the nature and malleability of motivation.

\section{Benefits}

These results highlight some of the benefits of motivation tracking. First, program administrators can assess the satisfaction of students and arrange for individual conferences and targeted interventions. This occurred with some participants in this study, such as participants 11,29, and 34 (see Table 3). Having the motivation levels during the term prompted their advisors to seek them out and help them address thei individual issues. Second, having multiple measurements of average class motivation helped administrators and teachers identify interventions that had a positive impact on motivation. This type of data can also help teachers and administrators determine whether a particular class section may have problems, enabling them to implement remediation. Third, continued use of a tracking program can assist in planning for future cohorts. Specifically, feedback regarding various program elements makes it possible to revise them.

The benefits of the motivational interventions for participants are less clear. Although it would be tempting to simply look at the general increase in reported motivation (see Figure 1), this would be overly simplistic. There is insufficient data to make a determination. The main problem is that some of the follow-up questions on the surveys might not have made the link between the intervention and participants' motivation clear. Moreover, as the effects of any specific intervention may manifest themselves later, a summative survey targeting all interventions would have been beneficial. Future iterations of this tracking program will seek to remedy these issues.

\section{Limitations}

Much of the data collected through this tracking program was incomplete and unsuitable for statistical analyses. Because of absences and lateness, not all students submitted full data sets (see Table 3), which might have skewed results. Moreover, there is no guarantee that another cohort would demonstrate similar motivational patterns. Consequently, interpretation of this information must be moderated by other information about the participants and the program.

Furthermore, the greatest benefit came from real-time, actionable feedback. That required someone to translate, process, compile, and regularly report this information to course teachers, program administrators, and advisors. For this project, processing often could not keep pace with data collection, resulting in lost opportunities for interventions. This suggests that those implementing a motivational intervention program must schedule time to process the information in a timely manner and distribute it immediately, clearly an issue for already busy teachers and program administrators.

\section{Conclusion}

Understanding the changes that occur in students' motivational levels during the term should prove useful in identifying those at risk and helping them make focused changes that might lead to improved motivation. As the correlation between motivation and educational achievement is well known, understanding how motivation might be positively influenced and what interventions are most effective was clearly the next avenue for motivation research. This study has begun that process by first identifying the initial motivational level of participants and then taking steps to address issues in their motivation and make appropriate changes.

The next step is to determine which intervention sessions are most efficacious for improving learner motivational levels and when these should take place. Finally, feedback about student motivation can provide valuable information to educators that allows demotivation to be promptly addressed. This paper shared results from one program's motivational intervention. Despite gaps, the insights garnered indicate these are a promising avenue for addressing issues in students' motivation.

\section{Bio Data}

Brad Visgatis and Masao Tada are professors at Osaka International University. Both have been researching aspects of language learning in Japan for more than 30 years. They have other interests; however, work and research have consumed the time that they need for these. 


\section{Acknowledgements}

Thanks go to the editors, two anonymous JALT Post Conference Publication reviewers, and Dr. Tamara Swenson for their comments and suggestions on this manuscript.

\section{References}

Dörnyei, Z. (1994). Motivation and motivating in the foreign language classroom. Modern Language Journal, 78(3), 273-284. https://doi.org/10.1111/j.1540-4781.1994.tb02042.x

Dörnyei, Z. (2003). Attitudes, orientations, and motivations in language learning: Advances in theory, research, and applications. Language Learning, 53(S1), 3-32. https://doi.org/10.1111/1467-9922.53222

Dörnyei, Z. (2009). The L2 motivational self system. In Z. Dörnyei \& E. Ushioda (Eds.), Motivation, language identity and the L2 self (pp. 9-42). Bristol, UK: Multilingual Matters.

Dörnyei, Z., \& Chan, L. (2013). Motivation and vision: An analysis of future L2 self images, sensory styles, and imagery capacity across two target languages. Language Learning, 63(3), 437-462. https://doi.org/10.1111/lang.12005

Dörnyei, Z., \& Csizár, K. (1998). Ten commandments for motivating language learners: results of an empirical study. Language Teaching Research, 2(3), 203-229. https://doi.org/10.1177/136216889800200303

Dörnyei, Z., MacIntyre, P. D., \& Henry, A. (2014). Introduction: Applying complex dynamic systems principles to empirical research on L2 motivation. In Z. Dörnyei, P. D. Maclntyre, \& A. Henry (Eds.), Motivational dynamics in language learning (pp. 1-7). Bristol, England: Multilingual Matters.

Dörnyei, Z., Muir, C., \& Ibrahim, Z. (2014). Directed motivational currents. In D. Lasagabaster, A. Doiz, \& J. M. Sierra (Eds.), Motivation and foreign language learning (pp. 9-29). Amsterdam, The Netherlands: John Benjamins.

Duff, P. A., \& Uchida, Y. (1997). The negotiation of teachers' sociocultural identities and practices in postsecondary EFL classrooms. TESOL Quarterly, 31, 451-486. https://doi.org/10.2307/3587834

Duhigg, C. (20012). The power of habit. New York, NY: Random House.

Gardner, R. C., Masgoret, A. M., Tennant, J., \& Mihic, L. (2004). Integrative motivation: Changes during a year-long intermediate-level language course. Language Learning, 54(1), 1-34. https://doi.org/10.1111/j.1467-9922.2004.00247.x

Hayashi, H. (2005). Identifying different motivational transitions of Japanese ESL learners using cluster analysis; Self-determination perspectives. JACET Bulletin, 41(1), 1-17. https://doi.org/NAID: 110006318211
Irie, K. (2003). What do we know about the language learning motivation of university students in Japan? Some patterns in survey studies. JALT Journal, 25(1), 86-100.

https://doi.org/10.37546/JALTJJ25.1-4

Kimura, Y., Nakata, Y., \& Okumura, T. (2001). Language learning motivation of EFL learners in Japan: A cross-sectional analysis of various learning milieus. JALT Journal, 23(1), 47-68. https://doi.org/10.37546/JALTJJ23.1-3

Moodle Pty., Ltd. (2019). Moodle (3.2) [Learning management system]. https://moodle.com/

Morgenroth, T., Ryan, M. K., \& Peters, K. (2015). The motivational theory of role modeling: How role models influence role aspirants' goals [10.1037/gpr0000059]. Review of General Psychology, 19(4), 465-483. https://doi.org/10.1037/gpr0000059

Muir, C., \& Dörnyei, Z. (2013). Directed motivational currents. Studies in Second Language Learning and Teaching, 3(3). Retrieved from http://www.ssllt.amu.edu.pl

Oxford, R. L., \& Burry-Stock, J. A. (1995). Assessing the use of language learning strategies worldwide with the ESL/EFL version of the the Strategy Inventory for Language Learning (SILL). System, 23(1), 1-23. https://doi.org/10.1016/0346-251X(94)00047-A

Oxford, R. L., \& Ehrman, M. E. (1995). Adults' language learning strategies in an intensive foreign language program in the United States. System, 23(3), 359-386. https://doi.org/10.1016/0346-251X(95)00023-D

Rost, M. (2006). Generating student motivation. Worldview. London: Pearson Longman. Retrieved from http://www.pearsonlongman.com/ae/worldview/motivation.pdf

Sawyer, M. (2006, November). Motivation and identity in flux: 8 years of EFL. Paper presented at JALT2006: The Japan Association for Language Teaching 32rd International Conference, Kitakyushu, Japan, Kitakyushu, Japan.

Visgatis, B. L. (2014). English-related out-of-class time use by Japanese university students. Temple University. ProQuest Dissertations number 3637511. https://search.proquest.com/

Weiner, B. (1990). History of motivational research in education. Journal of Educational Psychology, 82(4), 616. https://doi.org/10.1037/0022-0663.82.4.616

Yamashiro, A., \& McLaughlin, J. (2001). Relationships among attitudes, motivation, anxiety, and English language proficiency in Japanese college students. In P. Robinson, M. Sawyer, \& S. Ross, Second language acquisition research in Japan (pp. 113-127). Tokyo, Japan: JALT.

Yashima, T., Zenuk-Nishide, L., \& Shimizu, K. (2004). The influence of attitudes and affect on willingness to communicate and second language communication. Language Learning, 54(1), 119-152. https://doi.org/10.1111/j.1467-9922.2004.00250.x 